\title{
Anestesia untuk Seksio Sesarea pada Pasien dengan Korioamnionitis dan Trombositopenia
}

\author{
Dina Paramita, Ery Laksana \\ Departemen Anestesiologi \& Terapi Intensif Fakultas Kedokteran Universitas Diponegoro-RSUP Dr. Kariadi \\ Semarang
}

\begin{abstract}
Abstrak
Infeksi maternal adalah salah satu komplikasi perinatal yang paling umum terjadi. Kejadian kehamilan dengan korioamnionitis merupakan 1\% dari kasus di Amerika atau di negara maju sedangkan di negara berkembang kasus ini lebih tinggi. Pasien G3P1A1 31 minggu, umur 23 tahun. Pada pemeriksaan didapatkan hemodinamik stabil dengan tekanan darah:110/70 $\mathrm{mmHg}$, laju nadi: 76x/menit, laju nafas: $18 \mathrm{x} / \mathrm{menit}$, suhu $38^{\circ} \mathrm{C}$, kesadaran compos mentis, kontak baik. Pada pemeriksaan jantung dan paru dalam batas normal. Pemeriksaan laboratorium didapatkan Hb: 7,2 g/dl, trombosit: 12.000 /ul, lekosit: 27,5/ul, SGOT: 210/ul, SGPT: 141/ul. Pasien diputuskan untuk dilakukan seksio sesarea emergensi. Persiapan operasi yang sebelumnya dilakukan transfusi dengan trombosit konsentrat 3 kolf. Pada saat induksi hemodinamik stabil dilakukan induksi di ruang operasi dengan fentanyl $50 \mathrm{ug}$, propofol $2 \mathrm{mg} / \mathrm{kg} \mathrm{BB}$, rokuronium $0,6 \mathrm{mg} / \mathrm{kgBB}$, dan pemeliharaan anestesi dengan sevofluran, $\mathrm{N}_{2} \mathrm{O} / \mathrm{O}_{2}$. Selama operasi hemodinamik pasien stabil, saturasi oksigen $\left[\mathrm{SpO}_{2}\right] 99 \%$, operasi dilakukan selama 1 jam, lahir bayi dengan berat badan 1200 gram, dan dirawat di bangsal bayi resiko tinggi. Pascabedah pasien sadar penuh dilakukan ekstubasi dan diberikan masker oksigen 6 lt/ mnt dan pasien dirawat di ICU. Pada pemeriksan didapatkan hasil analisa gas darah normal dan kenaikan trombosit yang bertahap. Pada hari ke 3 mencapai 40/ul disertai dengan menurunnya jumlah lekosit dan suhu pasien normal. Pasien diputuskan pindah bangsal dengan rawat bersama dengan penyakit dalam.
\end{abstract}

Kata kunci: anestesia, korioamnionitis, seksio sesarea

\section{Anaesthetic for Caesarean Section in Patient with Chorioamnionitis and Thrombositopenia}

\begin{abstract}
Maternal infection is one of the most common perinatal complications. The incidence of pregnancy with chorioamnionitis constitutes $1 \%$ of cases in the United States or in developed countries whereas in developing countries this case is higher. G3P1A1 patient 31 weeks, age 23 years. on examination, hemodynamically stable blood pressure: $110 / 70 \mathrm{mmHg}$, pulse rate: $76 \mathrm{x} / \mathrm{min}$, respiratory rate: $18 \mathrm{x} / \mathrm{min}$, temperature $38^{\circ} \mathrm{C}$, composmentis awareness, good contact, on heart and lung examination are within normal limits. Laboratory examination obtained Hb: 7.2 g / dl, platelets: 12,000 / ul, leukocytes: 27.5 / ul, SGOT: 210 / ul, SGPT: 141 / ul. The patient was decided to do cesarean section. Preparation of surgery was done before transfusion with platelet concentrate 3 colf. At the time of stable hemodynamic induction, then induction was carried out in the operating room with 50 ug fentanyl, propofol $2 \mathrm{mg} / \mathrm{kg} \mathrm{BW}$, rocuronium $0.6 \mathrm{mg} / \mathrm{kgBW}$ and maintenance of anesthesia with sevoflurane, $\mathrm{N}_{2} \mathrm{O} / \mathrm{O}_{2}$. During hemodynamic surgery the patient is stable, $\mathrm{SpO} 2$ is $99 \%$, surgery is carried out for 1 hour, a baby is born weighing 1200 grams and is treated in a high-risk infant ward. After surgery the patient was fully conscious, extubated, and the patient was treated in the ICU. In the examination, the result of normal blood gas analysis and increased a platelets accompanied by a decrease in the number of leukocytes and normal temperature. The patient was decided to move the ward with care together with internal medicine.
\end{abstract}

Key words: anesthesia, chorioamnionitis, section secarea 


\section{Pendahuluan}

Infeksi maternal adalah salah satu komplikasi perinatal yang paling umum terjadi. Kejadian kehamilan dengan korioamnionitis merupakan 1-4\% dari kasus di Amerika atau di negara maju sedangkan di negara berkembang kasus ini lebih tinggi dan menjadikan komplikasi sekitar $40-70 \%$ terhadap persalinan preterm dengan ketuban pecah dini. ${ }^{1,2}$ Korioamnionitis tidak dianggap mutlak untuk indikasi seksio sesarea kecuali didapatkan indikasi lain. ${ }^{3,4}$ Korioamnionitis merupakan radang dari selaput korion dimana cara penyebarannya ada 4 cara secara ascederen yaitu: naiknya dari vagina dan serviks, penyebaran hematogen melalui plasenta [infeksi transplasental], retrograde dari rongga peritoneum melalui tuba falopii, accidental pada waktu melakukan prosedur invasif. Jalur pertama merupakan hal tersering yaitu langsung dari vagina dan servix.,

Infeksi intrauterin secara ascenderen dibagi dalam 4 stadium yaitu: terjadi perubahan flora normal di vagina/serviks atau adanya organisme patologis [N. gonorrheae] di serviks, beberapa bentuk vaginitis dapat dijumpai pada manifestasi awal stadium 1, yang kedua organisme sudah masuk ke rongga intrauterin dan berada di desidua sehingga terjadi reaksi inflamasi lokal yang menyebabkan desiduitis, selanjutnya mikroorgnisme masuk ke korion dan amnion, infeksi menyebar ke pembuluh darah fetus [koriovasculitis] atau melalui amnion [amnionitis] kedalam ruang amnion, menyebabkan invasi mikroba pada ruang amnion atau infeksi intraamnion. Rupture membran bukan syarat untuk bisa terjadinya infeksi intraamnion oleh karena mikroorganisme mampu melewati membrane yang utuh, selanjutnya setelah masuk ke kantong amnion bakteri masuk ke fetus melalui berbagai jalur. ${ }^{7-9}$ Korioamionitis dapat menyebabkan berbagai komplikasi terhadap maternal dan neonatal. Komplikasi maternal yaitu: kelainan dalam persalinan, peningkatan kebutuhan oksitosin, peningkatan resiko persalinan dengan operasi sesarea, dan dapat meningkatkan komplikasi bedah seperti luka, abses panggul. Komplikasi neonatal yaitu: sepsis, pneuomonia, gangguan pernapasan dan kematian. Selain komplikasi neonatal, korioamnionitis juga bisa menyebabkan penurunan fungsi neurologis jangka panjang pada bayi dan kerusakan otak yanag menyebabkan cerebral palsy. ${ }^{8,10}$ Pembiusan pasien ini dilakukan dengan general anestesi dengan propofol, rocuronium, dan fentanyl. Dalam beberapa kepustakaan disebutkan bahwa demam tidak disebabkan karena efek dari regional anestesi, demam tetap harus dipantau dalam 48 jam ke depan dengan pemberian antibiotika dan hasil kultur. Teknik epidural maupun spinal dapat dilakukan selama tidak ada kontraindikasi. ${ }^{11,12}$ Walaupun angka kejadiannya jarang, tetapi kejadian korioamnionitis didapatkan setelah terjadinya ketuban pecah dini pada pasien. Pasien didiagnosis dengan korioamnionitis klinis jika didapatkan 2 dari gejala berikut ini: demam maternal, ibu/janin yang mengalami takikardi, lekositosis pada ibu, nyeri tekan uterus dan caran ketuban berbau busuk.

\section{Kasus}

\section{Anamnesis}

Pasien datang di UGD dengan G3P1A1, hamil 31 minggu, 23 tahun, janin 1 hidup intrauterin dengan keluhan nyeri perut bawah letak sungsang, bekas seksio sesarea $1 \mathrm{x}$, riwayat kehamilan sebelumnya: anak pertama keguguran hamil 2 minggu di RS Purwodadi, anak yang kedua perempuan lahir aterm dengan berat badan lahir 3400 gram atas indikasi panggul sempit di RS Kudus, usia sekarang 4 tahun dan sehat, anak ketiga hamil yang ini. Penyakit yang pernah diderita: asma -, hipertensi -, penyakit jantung -, obat-obatan yang sedang dikonsumsi: dexametason $5 \mathrm{mg}$.

\section{Pemeriksaan Fisik}

Pada pemeriksaan fisik didapatkan kesdaran pasien compos mentis, kontak baik didapatkan nyeri pada perut kanan bawah, pada pemeriksaan didapatkan tensi: 110/70 $\mathrm{mmHg}$; nadi: $76 \mathrm{x} /$ menit, laju nafas: $18 \mathrm{x} /$ menit, suhu: $38^{\circ} \mathrm{C}$, tinggi badan: $148 \mathrm{~cm}, \mathrm{BB}: 70 \mathrm{~kg}$. Pemeriksaan paru: suara dasar vesikuler, wheezing -/-, ronci -/-, pada pemeriksaan jantung: bising jantung I-II regular, tidak ada bising, tak ada murmur, pemeriksaan abdomen: hamil 31 minggu, bising usus + , pada 
Pemeriksaan Laboratorium sebelum operasi

\begin{tabular}{|c|c|c|c|c|}
\hline \multicolumn{2}{|c|}{$\begin{array}{l}\mathrm{Hb} \quad(\mathrm{g} / \mathrm{dl}) \\
\text { Hematokrit } \% \text { ) }\end{array}$} & 7,2 & GDS & 93 \\
\hline & 22 & $\begin{array}{l}\text { SGOT } \\
(\mathrm{U} / \mathrm{L}\end{array}$ & 200 \\
\hline \multicolumn{2}{|c|}{ Eritrosit (\%) } & 31,2 & $\begin{array}{l}\text { SGPT } \\
(\mathrm{U} / \mathrm{L})\end{array}$ & 140 \\
\hline \multicolumn{2}{|l|}{$\mathrm{MCH}$ (pg) } & 96 & $\begin{array}{l}\text { Ureum } \\
(\mathrm{mg} / \mathrm{dl})\end{array}$ & 3,2 \\
\hline \multicolumn{2}{|l|}{$\mathrm{MCV}(\mathrm{fl})$} & 25,7 & $\begin{array}{l}\text { Creatinin } \\
(\mathrm{U} / \mathrm{L})\end{array}$ & 0,8 \\
\hline MCHC & $(\mathrm{g} / \mathrm{dl})$ & 25,7 & Elektrolit: & \\
\hline $\begin{array}{l}\text { Leukosit } \\
\text { / 1) }\end{array}$ & $(10$ & 27.000 & $\begin{array}{l}\text { Natrium } \\
(\mathrm{mmol} / \mathrm{dl})\end{array}$ & 144 \\
\hline $\begin{array}{l}\text { Trombosit } \\
/ 1\end{array}$ & (10 & 12.000 & $\begin{array}{l}\text { Kalium } \\
(\mathrm{mmol} / \mathrm{dl})\end{array}$ & 3,3 \\
\hline RDW & & 20,4 & $\begin{array}{l}\text { Chloride } \\
(\mathrm{mmol} / \mathrm{dl})\end{array}$ & 110 \\
\hline MPV & & 9,4 & $\begin{array}{l}\text { Albumin } \\
(\mathrm{g} / \mathrm{L})\end{array}$ & 3,4 \\
\hline
\end{tabular}

ekstremitas: tidak didapatkan udem. Diagnosis: pasien G3P1A1 dengan koriomanionitis dan trombositopenia, akan dilakukan seksio dengan status fisik ASA II.

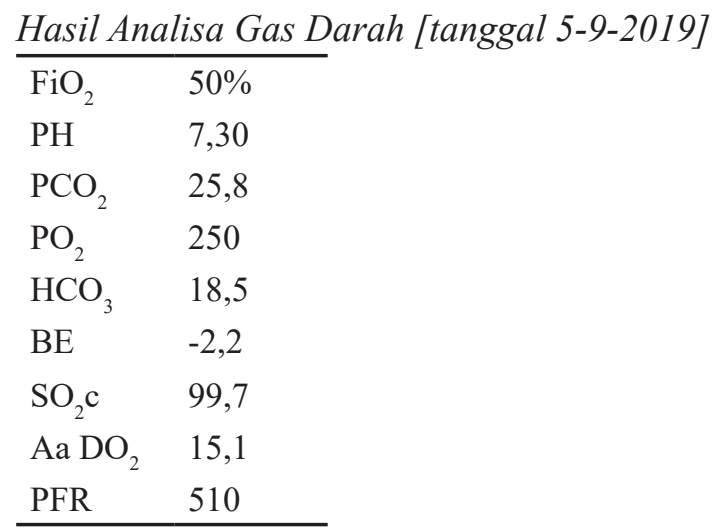

\section{Pengelolaan Anestesi}

Dilakukan terapi rutin yaitu pemasangan infus RL dengan tetesan $20 \mathrm{tpm}$, terapi antibiotika eritromysin peroral $500 \mathrm{mg}$ tiap 6 jam, dan rawat

Adapun perkembangan pasien selama di ICU sebagai berikut:

\begin{tabular}{|c|c|c|c|c|}
\hline Laboratorium & Sebelum operasi & $\begin{array}{l}\text { Hari ke } 1 \text { post operasi } \\
\text { di ICU }\end{array}$ & $\begin{array}{l}\text { Hari ke } 2 \text { post operasi } \\
\text { di ICU }\end{array}$ & $\begin{array}{l}\text { Hari ke } 3 \text { post } \\
\text { operasi di ICU }\end{array}$ \\
\hline $\mathrm{Hb}$ & 7,2 & 6,8 & 7,2 & 8 \\
\hline Hematokrit & 22 & 21 & 22,2 & 24,2 \\
\hline Eritrosit & 31,2 & & & \\
\hline $\mathrm{MCH}$ & 96 & & & \\
\hline $\mathrm{MCV}$ & 25,7 & & & \\
\hline $\mathrm{MCHC}$ & 25,7 & & & \\
\hline Leukosit & 27.000 & 17.000 & 10.000 & 10.000 \\
\hline Trombosit & 12.000 & 9000 & 23.000 & 40.000 \\
\hline RDW & 20,4 & & 20 & \\
\hline MPV & 9,4 & & 10,0 & \\
\hline GDS & 93 & 100 & 90 & \\
\hline SGOT & 200 & 140 & 80 & 80 \\
\hline SGPT & 140 & 100 & 75 & 70 \\
\hline Ureum & 32 & 30 & 20 & 20 \\
\hline Creatinin & 0,8 & 1,0 & 1,0 & 0,8 \\
\hline \multicolumn{5}{|l|}{ Elektrolit: } \\
\hline Natrium & 144 & 135 & 145 & 140 \\
\hline Kalium & 3,3 & 3,5 & 3,7 & 3,5 \\
\hline Chloride & 110 & & 90 & \\
\hline Albumin & 3,4 & 3,7 & 3,5 & \\
\hline
\end{tabular}


bersama dengan sejawat penyakit dalam sub hematologi, dan instruksi untuk usaha darah 3 PRC kembali. Pada pemeriksaan laboratorium didapatkan leukositosis, trombositopenia, anemia sedang, dan splenomegali. Saat itu dari sejawat obstetri diputuskan untuk operasi seksio emergensi. Selama persiapan operasi dilakukan transfusi.

Trombosit konsentrat III kolf dan PRC III kolf untuk persiapan operasi. Pengelolaan pasien: pasien dipuasakan jika memungkinkan, dilakukan premedikasi dengan metoclopramid sebelum operasi. Pasien didorong ke kamar operasi. Di ruang operasi, hemodinamik pasien stabil. Operator dan instrumen segera dipersiapkan dan melakukan dreping karena akan dikerjakan dengan general anestesi. Pembiusan dilakukan dengan general anestesi dengan propofol $2 \mathrm{mg} /$
Pengelolaan Pascabedah

Selama operasi hemodinamik stabil dan saturasi baik dimasukkan darah transfusi sebelum dan saat operasi karena pada pasien ini ditemukan adanya trombositopeni. Selesai operasi pasien dirawat di ICU, pasien terpasang masker oksigen 6 1/menit. Hari pertama didapatkan laboratorium hasil $\mathrm{Hb}$ naik 7,4 g\%, hasil analisa gula darah normal, trombosit naik perlahan, dan pada hari ke 3 dirawat trombosit mencapai 40.000 IU. Pasien diputuskan untuk kembali ke bangsal pada hari ke 3 dengan tetap dilanjutkan transfusi dan rawat bersama dengan sejawat penyakit dalam sub hematologi. Hasil X foto thoraks di ICU: Jantung tak tampak kelainan, Pulmo tak tampak kelainan

\section{Program Selanjutnya}

Rawat bersama dengan penyakit dalam sub hematologi. Hari ke 3 pasien pindah ke ruangan.

Obat-obat yang masuk selama dan setelah operasi

\begin{tabular}{lll}
\hline 4-9-2019 & 5-9-2019 & 6-9-2019 \\
\hline Injeksi metoclopramide & Injeksi metoclopamid & Injeksi metoclopamid \\
Injeksi ranitidine 50 mg/12 jam & Injeksi ranitidine 50 mg/12 jam & Injeksi ranitidine 50 mg/12 jam \\
Injeksi parasetamol 1 gr/24 jam & Injeksi parasetamol 1 gr/24 jam & Injeksi parasetamol 1 gr/24 jam \\
Ca glukonas 1 gr/12 jam & Injeksi ampisilin 1,5 gr/8 jam & Injeksi ampisilin 1,5 gr/8 jam \\
KSR 600 mg & Metronidazole 500 mg & Metronidazole 500 mg \\
Asam traneksamat 500 mg/8 jam & Asam traneksamat 500 mg/8 jam & Asam traneksamat 500 mg/8 jam \\
Morfin 1 gr/jam & Morfin 1 gr/jam & Morfin 1 gr/jam \\
Peroral: & Peroral: & \\
Vit A 200.000 IU/24 jam & Vit A 200.000 IU/24 jam & Vit A 200.000 IU/24 jam \\
Caco3 1 tab/jam & Caco3 1 tab/jam & Caco3 1 tab/jam \\
Vit B/C/SF 1 tab/8jam & Vit B/C/SF 1 tab/8jam & Vit B/C/SF 1 tab/8jam \\
\hline
\end{tabular}

$\mathrm{kgBB}$, fentanyl $50 \mathrm{ug}$, rocuronium $0,6 \mathrm{mg} /$ kg BB kemudian dilakukan pemasangan pipa endhotrakhea dan rumatan anestesi dengan sevofluran. Setelah itu dilakukan insisi pada pasien. Setelah insisi, 5 menit kemudian lahir bayi dengan BB 1200 gram menangis kuat dan selanjutnya di rawat di ruang BBRT [bangsal bayi resiko tinggi]. Selama operasi hemodinamik stabil, saturasi $99 \%$. Saat durante operasi dimasukkan darah 2 PRC. Selesai operasi pasien nafas spontan adekuat, dilakukan ekstubasi di ruang operasi. Pasien dirawat di ICU.

\section{Pembahasan}

Pada pasien ini didapatkan tanda-tanda yang mengarah ke korioamnionitis diantaranya: demam, takikardi. Pada saat pemeriksaan laboratorium didapatkan tanda leukositosis. Ada beberapa pemeriksaan lanjutan yang bisa dilakukan jika operasi ini bersifat elektif atau akan dilakukan tindakan evaluasi yaitu; pemeriksaan protein $\mathrm{C}$ reaktif [CRP], pemeriksaan cairan ketuban dan histopatologi plasenta. ${ }^{1,3}$ Walaupun angka kejadiannya jarang, tetapi kejadian korioamnionitis didapatkan setelah terjadinya 
ketuban pecah dini pada pasien. Pasien didiagnosis dengan korioamnionitis klinis jika didapatkan 2 dari gejala berikut ini: demam maternal, ibu/janin yang mengalami takikardi, lekositosis pada ibu, nyeri tekan uterus dan caran ketuban berbau busuk. ${ }^{2,4}$ Pada pasien ini terdapat peningkatan dari fungsi hepar tetapi anamnesa dan tanda-tanda kenaikan dari fungsi hepar tidak ditemukan diantaranya: ikterik pada pasien, sering lelah, riwayat penyakit hati sebelumnya disangkal. Pada pemeriksaan hari ke dua jumlah menurun dan hari ke 3 sudah kembali normal. ${ }^{6}$

Pada pasien ini didapatkan hasil trombosit yang menurun dimana merupakan kontraindikasi apabila dilakukan anestesi regional. Tindakan anestesi regional [spinal maupun epidural] boleh dikerjakan jika memenuhi syarat dan sebaiknya dengan diterapi antibiotka sebelum operasi. ${ }^{11}$ satu penelitian melaporkan bahwa anestesi epidural sebagi pencetus pada febris pasien [pada tindakan pasien dengan epidural labour analgesia] dikarenakan pemberian obat pada ibu nifas yang sedang demam dapat menyebarkan infeksi ke sistem saraf pusat dan menyebabkan sekuel neurologis, serta terdapat kasus abses pada epidural persalinan. Namun, studi epidemiologi tidak menunjukkan hal tersebut. Penelitian lain melaporkan 0,2-1,2 per 10.000 kejadian abses epidural spontan pada populasi pasien di rumah sakit umum. ${ }^{11,12}$

Pada pasien didapatkan trombosit yang sangat rendah, tetapi tidak didapatkan perdarahan spontan karena pada korioamnionitis jarang ditemukan keadaan trombositopeni yang sangat rendah, maka dilakukan rawat bersama dengan penyakit dalam sub hematologi. Adapun kriteria trombositopenia sendiri dibagi menjadi 3 yaitu: trombositopeni ringan [trombosit 100.000-150.000/ul], trombositopeni sedang [trombosit 50.000-100.000/ul], trombositopenia berat [trombosit jumlahnya $<50.000 / \mathrm{ul}$. Trombositopenia menyebabkan ibu dan janin berada dalam resiko yang lebih besar untuk mengalami perdarahan, terutama apabila kadar trombosit kurang dari 20.000/ul. Anibodi IgG antitrombosit yang beredar di dalam sirkualsi darah memiliki kemampuan untuk melewati sawar darah plasenta dan menyebabkan trombositopneia pada fetus yang kemudian akan bermanifestasi seperti purpura, ekimosis, melena dan perdarahan intracranial pada masa neonatus. ${ }^{13,14}$ Pada pasien didapatkan anemia sedang, dimana setelah ditranfusi III kolf PRC terdapat peningkatan pada hari 1 seteah operasi, dan hari kedua dan seterusnya terdapat kenaikan yang baik. Adapun kriteria anemia adalah: $\mathrm{Hb}$ $<7$ gr $/ \%$ disebut anemia berat, $\mathrm{Hb} \quad 7-8$ gr $\%$ disebut anemia sedang, $\mathrm{Hb} 9-10 \mathrm{gr} \%$ disebut anemia ringan sedang $\mathrm{Hb}>11$ gr\% dikatakan tidak didapatkan anemia. Adapun klasifikasi anemia dalam kehamilan dibagi menjadi: anemia defisiensi besi yang disebabkan karena kekurangan zat besi, Anemia megaloblastik yang disebablan karena kekurangan asam folik, Anemia hipoplastik yang disebabkan karena hipofungsi dari sumsum tulang untuk membentuk sel darah merah baru, dan Anemia hemolitik yang disebabkan karena penghancuran atau pemecahan sel darah merah yang lebih cepat dari pembuatannya. Anemia meningkatkan resiko bagi ibu dan neonatus. Pada kehamilan dapat mneghambat pertumbuhan janin, berat badan lahir rendah, kelahiran premature, sedangkan pada janin akan mempengaruhi perkembangan otak janin. ${ }^{14}$

\section{Simpulan}

Sampai saat ini tidak ada pedoman yang pasti untuk ahli anestesi dalam pilihan anestesi untuk ibu melahirkan dengan demam. Penatalaksanaan anetesi pada pasien dengan demam harus dilakukan berdasarkan rasio resiko terhadap manfaat individu, indikasi kebidanan, urgensi, dan rute pengiriman pasca operasi. Pemilihan teknik anestesi pada pasien hamil dengan korioamnionitis bisa dengan anestesi general mapun regional tergantung dari keadaan pasien saat akan dilakukan tindakan seksio sesarea, tindakan emergensi, atau tidak, dan kontraindikasi dilakukannya anestesi general maupun regional. Pada kasus diatas digunakan teknik anestesi general karena didapatkan kontraindikasi untuk regional yaitu didapatkan trombositopeni berat pada pasien ini. Pasien ini hemodinamik stabil baik sebelum dan setelah tindakan operasi karena 
setelah operasi pemeriksaan darah menunjukkan trombosit yang sedikit kenaikannya, maka dilakukan rawat bersama dengan sejawat penyakit dalam sub hematologi.

\section{Daftar Pustaka}

1. $\mathrm{Su}$ BH. Histological chorioamnionitis and neonatal outcome in preterm infants. Pediatr Neonatol. 2014;55(2):154-5.

2. Galinsky R, Polglase GR, Hooper SB, Black MJ, Moss TJM. The consequences of chorioamnionitis: Preterm birth and effects on development. J Pregnancy. 2013; 2013: 412831.

3. Bastek JA, Weber AL, McShea MA, Ryan ME, Elovitz MA. Prenatal inflammation is associated with adverse neonatal outcomes. Am J Obstet Gynecol. 2014 May;210(5):450.

4. Higgins RD, Saade G, Polin RA, Grobman WA, Buhimschi IA, Watterberg $\mathrm{K}$, et al. Evaluation and management of women and newborns with a maternal diagnosis of chorioamnionitis: Summary of a Workshop. Obstetrics and Gynecology. 2016; 127: 42636.

5. Peng CC, Chang JH, Lin HY, Cheng PJ, Su $\mathrm{BH}$. Intrauterine inflammation, infection, or both (Triple I): A new concept for chorioamnionitis. Pediatr Neonatol. 2018 Jun;59(3):231-7.

6. Puspita RD, Rodiani, Saputra BA. Kehamilan dengan trombositopenia. Medula, 2018, April;(8): 1.
7. Asif N, Hassan K. Thrombocytopenia in pregnancy. Hematology Transfusi int.j.2017, $5 ; 307-9$

8. Talaulikar VS. Anemia in pregnancy. University colege Hospital, London UK https;//www.glown.com/critical current. issue/page/25.

9. Rahmaniar H, Purnomo AB, Dewantiningrum J, Kristanto H, Arkhaesi N. Hubungan gambaran hitung jenis leukosit maternal dengan koriomnionitis pada ketuban pecah dini [studi pada usia kehamilan 28-42 minggu]. Med Hosp. 2018; (5); 1;5-10.

10. Murphy KE, Carthy FP. Chorioamnionitis: from pathogenesis to treatment. Clinical microbiologi and infection. 2011, 17; 1304 11.

11. Andrew WM, Tita AN. Diagnosis and management of clinical chorioamnionitis. NIH Public Access. 2010 june;37 [2];339-54.

12. Krzyztof MK. The febrile parturient : choice of anesthesia. Shouter African journal of Anesthesia and Analgesia. 2002; 8: 5-20.

13. Nel MR, Robinson PN, Lucas. Sepsis in obstetric and the role of anaesthetis. International Journal of Obstetric Anaesthesia. 2012, 21; 56-67.

14. Erando CL, Gimeno AM. Neuroaxial regional anaesthesia in patient with active infection and sepsis : A clinical narrative review. Turk J Anaesthesiol Reanim 2018; 46: 8-14. 